\title{
Analysis on the Factors Affecting College English Teaching Quality
}

\author{
Xiaoyan Wang ${ }^{1}$ \\ ${ }^{1}$ Jiangxi Institute of Economic Administrators, Nanchang, Jiangxi, 330000
}

Keywords: English teaching; affecting factors; teaching quality

\begin{abstract}
The quality of college English teaching has always been a matter of widespread concern. From the national perspective, the total investment in English teaching is very large, but there have always been problems of high input and low output. As an important stage of English teaching, the quality of college English teaching is a concentrated expression of the effectiveness of the English education system in the country. Therefore, it is of great significance to study its influencing factors. This paper tries to make a comprehensive analysis of the factors that influence the quality of college English teaching from the aspects of teaching objectives, students, teachers, teaching management, and teaching environment, so as to lay a foundation for the construction of college English teaching quality evaluation system.
\end{abstract}

\section{Introduction}

The current popularity of college English teaching in our country is high, but its teaching effect is not satisfactory. In the era of various new teaching methods and educational ideas, China's college English teaching actually has many problems. One of them is that the time for college English teaching in our country is long, but it has little effect. Many students study English only to pass the college English level 46 exam. This passive learning motivation often results in a passive learning mode, which affects the learning effect. On the other hand, the main purpose of college English teaching is still not really out of the category of exam-oriented education. Many students can get a good surface learning effect in a short period of time through the topic-specific training and sea tactics. Relevant English tests have received so-called certificate of proficiency, but these are more limited to written English skills [1]. When they want to use English to communicate successfully and properly, great difficulties are revealed. So, how can we really improve the quality of college English teaching and subsequently achieve better teaching results? This is a question that every university English teacher should seriously consider. In many cases, it is regrettable that there is no agreement between the efforts made by English teachers and the effects of student learning.

\section{Factors Influencing the Effectiveness of College English Teaching}

One is learning motivation. Learning motivation is not strong or passive learning, students' learning must be negative, on the contrary, a clear and strong learning motivation can increase learning pleasure, thereby improving learning. The second is learning interest. Some college students often do not learn English because they like it. Studies in educational psychology show that learners' interests play a crucial role in foreign language learning. It is the best teacher to learn. There is a positive relationship between students' interest in learning and teaching effectiveness. The third is the polarization of students. College English teaching is a public foundation course for all undergraduates. Teachers often fall into an embarrassing situation in order to take into account the different foundations of the students, and have a negative impact on college English teaching. Fourth, the content of education is obsolete. As the teaching materials cannot be updated in time, students' interest is frustrated and the teaching effect is affected. In addition, the means of college English education in our country are still lagging behind. Students are still more passive knowledge recipients and cannot truly become masters of the classroom. This seriously hampers the subjective initiative of student learning. The fifth is the traditional system. College English teaching has not always taken a long time and the output is low. At present, the college-style college English 
teaching model does not integrate well with the actual needs and applications of the society. It focuses on examinations and focuses on certificates. The severe exam psychology influences the effect of college English teaching, making the teaching reform emphasis on the form instead of the essential revolution [2].

The Department of Higher Education of the Ministry of Education has formulated specific and clear training objectives for college English teaching based on the actual needs of the society and the actual situation of teachers and learners: To develop students' comprehensive English application skills, especially the listening and speaking skills, so that they can English can effectively communicate oral and written information in the work and social interactions, and at the same time enhance their self-learning ability and improve their comprehensive cultural qualities to meet the needs of China's social development and international exchange.

With clear training objectives, in order to adapt to the new situation of the development of higher education in China, to deepen teaching reform, and to improve the quality of teaching to meet the needs of the nation and society in the new era for talent cultivation, we should formulate scientific and systematically based on the actual conditions of our school. The individualized college English syllabus translates these goals into teaching plans, making choices for the purpose, content, form, and method of foreign language teaching and guiding college English teaching. 2. Psycholinguistic studies have shown that there are many factors that affect learners, such as age, gender, etc.; emotional factors, such as learning motivation, learning attitude, and personality characteristics; and cognitive factors, such as intelligence, Linguistic learning, learning strategies, etc. Wen Qiufang divided the learner's factors into two categories: One is the controllable factor, which refers to those factors that can be changed by the learner's own efforts, such as motivation, attitude, and strategy; the other is the uncontrollable factor, which refers to those who rely on learning. Factors that cannot be changed by one's own efforts, such as gender, intelligence, linguistic ability, personality traits, students' past English proficiency, and teachers' teaching quality.

Under the new student-centered model of college English teaching (especially in the context of multimedia-assisted teaching), teachers need to update their teaching concepts, improve their teaching methods, update their teaching models and knowledge structure, and improve their overall English teaching and teaching research. New teaching goals, teaching methods, and higher levels of new school enrollment also require teachers to improve their own business. Teachers' personal qualities and related factors directly affect the quality of college English teaching. Excellent college English teachers should have the following qualities: First, professional knowledge is solid, rich, and professional skills are strong; second, they must acquire linguistics, foreign language learning theory, and test theory, etc., constantly update their teaching concepts, understand students' psychology and second language acquisition. The basic laws and teaching methods are flexible. Third, they are fluent in Chinese and Western cultural knowledge and are knowledgeable. They can infiltrate the cultural connotations in English teaching and have a depth of lectures. The fourth is mastering modern education technology, and can use multimedia and other computer-assisted teaching methods. Optimize the teaching process on the computer. Fifth, mentors and friends who are approachable, humorous and cheerful, have active thoughts, love and respect for work, strong sense of responsibility, strong scientific research ability, good at communicating with students, and being a student.

For a long time, the formulation of foreign language teaching goals in China is mainly through the form of a syllabus. "College English Syllabus" consists of the outline itself, four appendices (Glossary, Grammatical Structure Table, Function Idea Sheet, Language Skills List), references, and outline "Revised Explanation". The outline itself includes teaching objects and teaching. Objectives, teaching arrangements, tests, problems that should be noted in teaching, etc. The formulation of a foreign language syllabus should be a product of the national language and language education center and the analysis of the needs of the society and individuals for the teaching of foreign languages. It must also be a document formulated strictly in accordance with the rules of foreign language teaching. It must reflect the relevant subject areas, especially foreign language teaching. Theoretical research, psychology, and pedagogy are the latest teaching and research results; at the 
same time, curriculum design should also take into account innovations in science and technology, especially innovations in computers and networks [3]. In the study of foreign language teaching theory, the teaching method has attracted considerable attention. Different teaching methods will lead to completely different teaching effects. The main schools of modern foreign language teaching methods are: oral grammar and situational communication, auralism, communicative approach, systemic response, silence, community learning, natural law, and suggestion. In theory, according to different teaching objects, teaching contents and the size of teaching classes, synthesizing different teaching methods should be the best method. However, there are still many teachers who are influenced by educational background and traditional teaching methods and concepts. In the process of implementation, they cannot effectively implement new teaching concepts, and often use certain methods (eg, grammar translation method, audiovisual method, communicative method). As the main method, the rest becomes a supplementary embellishment.

\section{Ways to Improve the Effect of College English Teaching}

The teaching effect depends directly on the professional quality of teachers. To improve the quality of college English teachers, colleges and universities should do a good job in three aspects. The first is to strengthen the training and training of English teachers in in-service universities so that the level of teaching they can adapt to is continuously improving. The second is to improve the teaching and research environment of college English teachers and stabilize and reserve teachers. As far as college English teachers themselves are concerned, they mainly cultivate their own qualities from three aspects. First, improve ideological and moral qualities. We must distinguish between moral and non-conformity, and raise the awareness of compliance with the norms and requirements of the teacher ethics [4]. Learn to understand advanced teachers' advanced educational ideas, advanced deeds and excellent qualities to inspire self moral emotions. Second, improve the basic business quality. College English teachers should first establish the concept of "live to the old, learn old". Strengthen the learning of English teaching theory at home and abroad, insist on listening, watching English broadcasts, English programs, and frequently reading foreign language education books and papers. He is also good at using various resources including students, textbooks, colleagues, experts, society, and networks to actively participate in scientific research. In addition, we must seize some opportunities for further training to improve the level of academic qualifications. Through systematic training, we can understand the latest educational concepts and professional knowledge of the profession. Third, improve psychological quality. The main approach is to correct self-cognitive attitudes and timely adjustment of emotional state, humbly listen to others' opinions. Finally, we must learn to actively reflect and make the right choice.

The goal of teaching is the focus of the teacher's lesson preparation. It is the source of motivation that causes changes in students' learning behavior. To this end, college English teachers should first understand the outline and use the textbook flexibly based on their goals. According to the actual situation of the students in the class, the sections of the material content are added or deleted. Second, develop a practical teaching plan. The premise for teachers to formulate teaching plans is to fully understand the teaching objectives and teaching requirements of the syllabus and to understand the students' cognitive level. Third, arrange reasonable homework assignments. Extra-curricular activities can consolidate the effects of teaching in the classroom and serve as a reminder of the new situation. College English teachers should arrange differentiated and targeted extra-curricular assignments for different students' cognitive styles. For students who are cheerful and lively and like to communicate, English extracurricular activities can be arranged relatively richly and flexibly. For independent students, because of their independent and careful features, it is more appropriate to arrange jobs such as English newspapers and periodicals. Through differential homework assignments, the enthusiasm of English learning in the whole class will be mobilized to increase the effectiveness of English learning.

According to the viewpoint of system theory, in the process of teaching, if various teaching elements are reasonable and appropriate to achieve a harmonious state, they will form a joint force to promote the improvement of teaching quality and promote the healthy development of students' 
quality. On the contrary, if they do not cooperate well enough, they will form a kind of force, and each element will not only exert its own advantages, but will also offset the functions of other elements and directly affect the teaching effect [5].

"There are laws and teaching methods, there is no law," and from a theoretical point of view, all methods of mobilizing students' enthusiasm following the teaching laws are good methods. College English can design teaching methods from various forms, perspectives, and levels according to different teaching contents. For example, for teaching content that needs to develop students' cooperative awareness, teaching methods such as group discussion, teamwork, and English short play can be adopted. For the teaching contents that need to improve students' practical abilities, situation simulation, role playing, improvisation, etc. can be adopted. teaching methods. In addition, the debate method can enable students to distinguish between right and wrong in class debates and gain more knowledge. Teachers can also use pictures, sounds, video clips, and other means to assist teaching, create a variety of scenarios to link the teaching content with reality, and enhance the effectiveness of their auditory input, in order to fully stimulate students' interest in learning.

\section{Conclusion}

This article analyzes the influence of teachers and college students on English teaching. From the perspective of teachers, the quality of teachers, the teaching methods, and the scientific goals of teaching are important factors. From a student perspective, learning interest and motivation are important influencing factors. To this end, improving the effectiveness of college English teaching can range from improving the quality of college English teachers, formulating scientific and rational teaching standards, creating a relaxed and pleasant teaching atmosphere, inspiring students' interest in learning English, and strengthening students' motivation for learning English.

\section{References}

[1] Wang Shouren. In order to improve the teaching quality in China's colleges and universities, to promote college English teaching reform [J]. Foreign Languages, 2006, (5): 3.

[2] Zhou Quanlin. Effects of many factors on teaching effectiveness in teacher role-play [J]. Journal of Xuchang Teachers College, 2002, (5):106

[3] Yu Fang, Ning Shuang. Multi-layer linear analysis of the influence of teacher background variables on teachers' teaching effects [J]. Psychological Development and Education, 2002, (4):70.

[4] Zheng Hong. Some Suggestions on Improving College English Teaching [J]. Talents, 2012, (17): 280.

[5] Liu Fengjie. Effect of classroom ecology on college English teaching [J]. Education Exploration, 2007, (3):79 